\title{
Expression and regulation of toll- like receptors (TLRs) in human intervertebral disc cells
}

\section{Journal Article}

\section{Author(s):}

Klawitter, Marina; Hakozaki, Michiyuki; Kobayashi, Hiroshi; Krupkova, Olga; Quero, Lilian; Ospelt, Caroline; Gay, Steffen; Hausmann, Oliver; Liebscher, Thomas; Meier, Ullrich; Sekiguchi, Miho; Konno, Shin-ichi; Boos, Norbert; Ferguson, Stephen J. (D); Wuertz, Karin

\section{Publication date:}

2014-09

Permanent link:

https://doi.org/10.3929/ethz-b-000090308

\section{Rights / license:}

In Copyright - Non-Commercial Use Permitted

\section{Originally published in:}

European Spine Journal 23(9), https://doi.org/10.1007/s00586-014-3442-4 


\title{
Expression and regulation of toll-like receptors (TLRs) in human intervertebral disc cells
}

\author{
Marina Klawitter • Michiyuki Hakozaki · Hiroshi Kobayashi • Olga Krupkova · Lilian Quero • \\ Caroline Ospelt · Steffen Gay · Oliver Hausmann - Thomas Liebscher • Ullrich Meier • \\ Miho Sekiguchi $\cdot$ Shin-ichi Konno $\cdot$ Norbert Boos $\cdot$ Stephen J. Ferguson $\cdot$ Karin Wuertz
}

Received: 26 June 2013/Revised: 10 June 2014/ Accepted: 25 June 2014/Published online: 5 July 2014

(C) Springer-Verlag Berlin Heidelberg 2014

\begin{abstract}
Purpose Although inflammatory processes play an essential role in painful intervertebral disc (IVD) degeneration, the underlying regulatory mechanisms are not well understood. This study was designed to investigate the expression, regulation and importance of specific toll-like receptors (TLRs) - which have been shown to play an essential role e.g. in osteoarthritis-during degenerative disc disease.

Methods The expression of TLRs in human IVDs was measured in isolated cells as well as in normal or
\end{abstract}

M. Klawitter, M. Hakozaki, and H. Kobayashi have equally contributed to the manuscript.

Electronic supplementary material The online version of this article (doi:10.1007/s00586-014-3442-4) contains supplementary material, which is available to authorized users. degenerated IVD tissue. The role of IL- $1 \beta$ or TNF- $\alpha$ in regulating TLRs (expression/activation) as well as in regulating activity of down-stream pathways $(\mathrm{NF}-\kappa \mathrm{B})$ and expression of inflammation-related genes (IL-6, IL-8, HSP60, HSP70, HMGB1) was analyzed.

Results Expression of TLR1/2/3/4/5/6/9/10 was detected in isolated human IVD cells, with TLR1/2/4/6 being dependent on the degree of IVD degeneration. Stimulation with IL-1 $\beta$ or TNF- $\alpha$ moderately increased TLR1/TLR4 mRNA expression (TNF- $\alpha$ only), and strongly increased TLR2 mRNA expression (IL-1 $\beta / T N F-\alpha$ ), with the latter being confirmed on the protein level. Stimulation with IL$1 \beta$, TNF- $\alpha$ or Pam3CSK4 (a TLR2-ligand) stimulated IL-6 and IL-8, which was inhibited by a TLR2 neutralizing antibody for Pam3CSK4; IL- $1 \beta$ and TNF- $\alpha$ caused NF- $\kappa B$ activation. HSP60, HSP70 and HMGB1 did not increase IL- 6 or IL- 8 and were not regulated by IL- $1 \beta / \mathrm{TNF}-\alpha$.

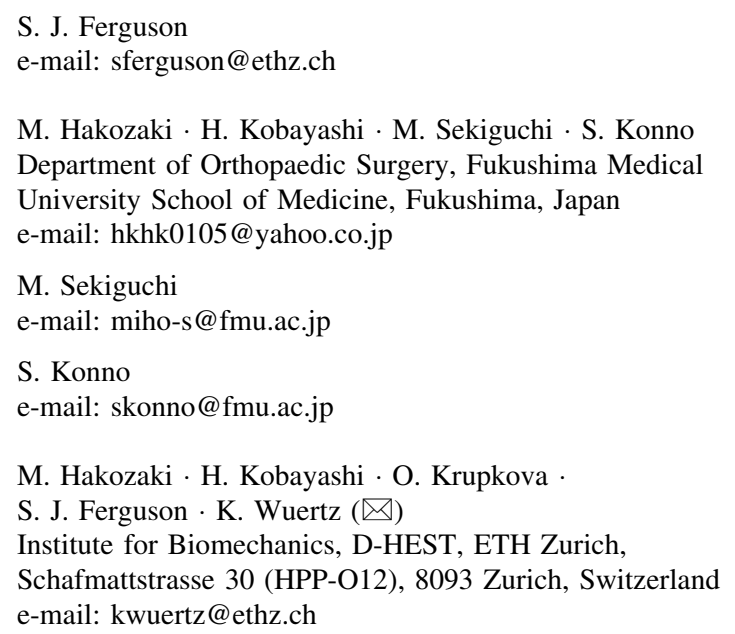


Conclusion We provide evidence that several TLRs are expressed in human IVD cells, with TLR2 possibly playing the most crucial role. As TLRs mediate catabolic and inflammatory processes, increased levels of TLRs may lead to aggravated disc degeneration, chronic inflammation and pain development. Especially with the identification of more endogenous TLR ligands, targeting these receptors may hold therapeutic promise.

Keywords Intervertebral disc degeneration - Toll-like receptor TLR activation - Inflammation - Heat shock protein HSP · High mobility group protein B1 HMGB1

\section{Introduction}

Degenerative intervertebral disc (IVD) disease is characterized by degradation of the extracellular matrix [1, 2] and is associated with increased expression of mediators of inflammation [3-5]. These mediators of inflammation (e.g. proinflammatory cytokines) are known to stimulate expression and activity of matrix degrading enzymes (e.g. MMP and ADAMTS) as well as to inhibit matrix protein synthesis, therefore aggravating the disease process [6, 7]. Regulation of proinflammatory cytokines and matrix degrading enzymes is, therefore, crucial for IVD homeostasis.

Toll-like receptors (TLRs) are expressed primarily in cell types that are involved in the first line of defense (e.g. dendritic cells, macrophages, neutrophils, monocytes or T/B cells) and have been implicated in innate immunity and, importantly for this study, in inflammation. During the past years, TLRs have also been detected in numerous non-

\author{
O. Krupkova \\ e-mail: okrupkova@ethz.ch \\ C. Ospelt - S. Gay \\ Center of Experimental Rheumatology, University Hospital \\ Zurich, Zurich, Switzerland \\ O. Hausmann \\ Center for Neurosurgery and Spine Surgery, St. Anna Clinic, \\ Lucerne, Switzerland \\ T. Liebscher · U. Meier \\ Unfallkrankenhaus Berlin, Berlin, Germany \\ e-mail: thomas.liebscher@ukb.de \\ U. Meier \\ e-mail: ullrich.meier@ukb.de \\ N. Boos $\cdot$ S. J. Ferguson $\cdot$ K. Wuertz \\ AOSpine Research Network, Duebendorf, Switzerland \\ N. Boos \\ Prodorso Centre for Spinal Medicine, Zurich, Switzerland
}

immune cells, e.g. in synovial fibroblasts [8, 9] and chondrocytes [10, 11]. In many tissues, expression of certain TLRs is increased in the presence of degeneration or disease, e.g. during osteoarthritis [11] or rheumatoid arthritis [12].

Microbial products are considered to be typical TLR ligands, indicating their primary role in the activation of innate immunity [13]. TLR2, for example, recognizes various Gram-positive bacterial compounds, whereas lipopolysaccharide LPS (a membrane component of Gramnegative bacteria) is known to act on TLR4 [14, 15]. However, more recent studies indicate that, in the absence of infection, TLRs may also recognize endogenous (nonbacterial) ligands, such as fragments of hyaluronic acid [16], heat shock protein 60 (HSP60), HSP70, high mobility group protein B1 (HMGB1) or fatty acids [17-21]. Importantly, HSP60, HSP70 and HMBG1 are expressed in isolated human IVD cells as well as in native IVD tissue with different degrees of degeneration (unpublished data). Ligand-induced initiation of TLR signaling can cause activation of nuclear factor (NF)- $\kappa \mathrm{B}$ and mitogen-activated protein kinases (MAPKs), leading to increased expression of proinflammatory cytokines such as IL-1, IL-6, IL-8 and TNF- $\alpha$ or certain matrix metalloproteinases (MMPs) [7, 22-26]. Therefore, endogenous ligand recognition could possibly induce catabolic signaling pathways and can thus directly contribute to degradative processes in the intervertebral disc, even in the absence of microbial components. However, no data are present to date that describes in detail the expression and regulation, as well as the role and importance, of TLRs in human IVD cells. Therefore, the aims of this study were:

1. To identify the basal expression of TLR1-10 in isolated human IVD cells.

2. To identify TLRs whose expression correlates with the degree of degeneration.

3. To analyze changes in the expression of these "correlated" TLRs by inflammatory factors typically present in vivo during degeneration (IL-1 $\beta$, TNF- $\alpha$ ).

4. To identify whether IL- $1 \beta$ and TNF- $\alpha$ cause activation of the respective TLR as well as down-stream activation of $\mathrm{NF}-\kappa \mathrm{B}$.

5. To identify whether stress-related proteins HSP60, HSP70 or HMGB1 play a role in TLR signaling during inflammatory disc disease.

This study provides evidence that TLR1, TLR2, TLR3, TLR4, TLR5, TLR6, TLR9 and TLR10 were expressed on the mRNA level in human IVD cells, with TLR1, TLR2, TLR4 and TLR6 being dependent on the degree of IVD degeneration. Exposure to IL-1 $\beta$ and TNF- $\alpha$ primarily stimulated gene and protein expression of TLR2, its potential target genes (IL-6, IL-8) and caused NF- $\kappa B$ 
activation. Although no specific TLR2 ligands could be identified in this study, targeting the TLR2 signaling pathway could be a promising strategy to reduce inflammatory and catabolic processes in the IVD and thus to treat painful degenerative disc disease.

\section{Methods}

\section{Ethical approval and grading}

The study was approved by the Gesundheitsdirektion Kanton Zurich, Switzerland (\#EK-16/2005) as well as by the Charité Ethikkommission, Germany (\#EA2/087/11). Informed consent was acquired from the patients in accordance with the local ethical guidelines.

Using pre-operative MRI, the degree of IVD degeneration was assessed according to Pfirrmann [27] with an adopted 4-grade classification scale as previously described [28], i.e. non-degenerated with normal disc height (grade 1), mildly degenerated with slight decrease in disc height (grade 2), moderately degenerated with a moderate decrease in disc height (grade 3 ) or severely degenerated with extensive loss in disc height (grade 4).

\section{Isolation and culture of intervertebral disc cells}

Freshly excised IVD tissue from patients undergoing spinal surgery due to degenerative disc disease, disc herniation or sequestration was enzymatically digested for cell isolation. Due to the degeneration status of most specimens (moderate to severe: grade 3-4) as well as the posterior surgical approach used in most cases, no separation of nucleus pulposus and annulus fibrosus was performed. Briefly, biopsies were minced and incubated with sterile $0.3 \%$ collagenase NB4 (Serva/Promega, Switzerland) and $0.2 \%$ dispase II (Roche Diagnostics, Switzerland) in phosphate-buffered saline (PBS) for 4-8 $\mathrm{h}$, the cell suspension was filtered using a $70 \mu \mathrm{m}$ cell strainer (BD Bioscience, Switzerland) and expanded up to passage 3 in a $2 \mathrm{D}$ monolayer culture system containing DMEM/F12 media (Sigma-Aldrich, Switzerland) with $10 \%$ FCS (Tecomedical, Switzerland), penicillin (50 U/ $\mathrm{mL})$, streptomycin $(50 \mu \mathrm{g} / \mathrm{mL})$, and ampicillin (125 ng/ $\mathrm{mL}$ ) (Invitrogen, Switzerland), with medium changes twice a week.

\section{Detection of basal TLR mRNA expression}

Expanded, but otherwise untreated cells from six patients with moderate to severe disc degeneration (grade 3-4) were harvested by trypsin treatment in passage 2 or 3 and mRNA was isolated with the PureLink RNA Mini
Kit (Ambion/Invitrogen, Switzerland) in combination with DNAse treatment (Invitrogen, Switzerland) according to the manufacturer's recommendation. For each sample, $1 \mu \mathrm{g}$ of mRNA was reverse transcribed to cDNA (Reverse Transcription Reagents, Applied Biosystems, Switzerland) and then used for real-time RTPCR measurements to detect toll-like receptors TLR1-10 in duplicate measurements as previously described [29]. Eukaryotic 18S ribosomal RNA (rRNA) levels were measured with a predeveloped primer/probe system (Applied Biosystems) and used as internal control $(\Delta \mathrm{Ct}$ method $=\mathrm{Ct}$ of gene of interest $-\mathrm{Ct}$ of $18 \mathrm{~S}$ RNA). For detailed information on primers see Table 1 . Based on the results, TLR1/2/3/4/5/6/9/10 were further investigated.

Changes in TLR mRNA expression with the degree of IVD degeneration

Frozen IVD tissue was obtained from patients undergoing spinal surgery for symptomatic degenerative disc disease, disc herniation, or spinal trauma.

Biopsies were allocated to grade $1,2,3$ or $4(n=5-10$, depending on degeneration grade and gene of interest), pulverized under liquid nitrogen and RNA was extracted using Trizol extraction (Sigma-Aldrich, Switzerland), followed by purification with the PureLink RNA Mini Kit (Ambion/Invitrogen, Switzerland) as previously described [30]. Real-time RT-PCR measurement was performed using TaqMan Gene Expression assays (Applied Biosystems, Switzerland) (chosen based on above mentioned experiments) as well as of TATA-box binding protein TBP (internal control). For primer details see Table 1. Gene expression was normalized to the housekeeping gene TBP ( $2^{-\Delta \mathrm{Ct}}$ method). Based on the results, TLR1, TLR2, TLR4 and TLR6 were further investigated.

\section{Detection of changes in TLR mRNA expression} upon stimulation with TNF- $\alpha$ or IL-1 $\beta$

Expanded cells in passages 2 or 3 from biopsies with degeneration grade 3-4 (i.e. moderate to severe) were rendered serum free for $2 \mathrm{~h}$ and then incubated with IL-1 $\beta$ and TNF- $\alpha$ in a time- and concentration-dependent manner to measure gene expression by real-time RT-PCR $(n=5$; only partially identical donors in both experiments, depending on available cell number). For the time course experiment, cells were incubated with recombinant IL-1 $\beta$ (5 ng/ml, Peprotech/LuBioScience, Switzerland) or TNF- $\alpha$ (100 ng/ml, Peprotech/LuBioScience, Switzerland) for 2, 6 or $18 \mathrm{~h}$ in serum-free medium. For the concentration dependency experiment, cells were treated for $18 \mathrm{~h}$ with different concentrations of IL- $1 \beta(0.1,1,5$, or $10 \mathrm{ng} / \mathrm{ml})$ or 
Table 1 Primers/probes

\begin{tabular}{|c|c|c|}
\hline Gene & Primers/probes (designed assays) & TaqMan $^{\circledR}$ \\
\hline TLR1 & $\begin{array}{l}\text { F: CAGTGTCTGGTACACGCATGGT } \\
\text { R: TTTCAAAAACCGTGTCTGTTAAGAGA } \\
\text { SYBRGreen }^{\circledR} \text { dye }\end{array}$ & Hs00413978_m1 \\
\hline TLR2 & $\begin{array}{l}\text { F: GGCCAGCAAATTACCTGTGTG } \\
\text { R: AGGCGGACATCCTGAACCT } \\
\text { P: TCCATCCCATGTGCGTGGCC (FAM/TAMRA) }\end{array}$ & Hs00152932_m1 \\
\hline TLR3 & $\begin{array}{l}\text { F: CCTGGTTTGTTAATTGGATTAACGA } \\
\text { R: TGAGGTGGAGTGTTGCAAAGG } \\
\text { P: ACCCATACCAACATCCCTGAGCTGTCAA (FAM/TAMRA) }\end{array}$ & Hs00152933_m1 \\
\hline TLR4 & $\begin{array}{l}\text { F: CAGAGTTTCCTGCAATGGATCA } \\
\text { R: GCTTATCTGAAGGTGTTGCACAT } \\
\text { P: CGTTCAACTTCCACCAAGAGCTGCCT (FAM/TAMRA) }\end{array}$ & Hs00152939_m1 \\
\hline TLR5 & $\begin{array}{l}\text { F: TGCCTTGAAGCCTTCAGTTATG } \\
\text { R: CCAACCACCACCATGATGAG } \\
\text { P: CCAGGGCAGGTGCTTATCTGACCTTAACA (FAM/TAMRA) }\end{array}$ & \\
\hline TLR6 & $\begin{array}{l}\text { F: GAAGAAGAACAACCCTTTAGGATAGC } \\
\text { R: AGGCAAACAAAATGGAAGCTT } \\
\text { SYBRGreen }^{\circledR}\end{array}$ & Hs00271977_s1 \\
\hline TLR7 & $\begin{array}{l}\text { F: TTTACCTGGATGGAAACCAGCTA } \\
\text { R: TCAAGGCTGAGAAGCTGTAAGCTA } \\
\text { P: AGAGATACCGCAGGGCCTCCCG (FAM/TAMRA) }\end{array}$ & \\
\hline TLR8 & $\begin{array}{l}\text { F: TTATGTGTTCCAGGAACTCAGAGAA } \\
\text { R: TAATACCCAAGTTGATAGTCGATAAGTTTG } \\
\text { P: TGATTTCCAGCCCCTGATGCAGC (FAM/TAMRA) }\end{array}$ & \\
\hline TLR9 & $\begin{array}{l}\text { F: GGACCTCTGGTACTGCTTCCA } \\
\text { R: AAGCTCGTTGTACACCCAGTCT } \\
\text { P: ACGATGCCTTCGTGGTCTTCGACAAA (FAM/TAMRA) }\end{array}$ & \\
\hline TLR10 & $\begin{array}{l}\text { F: CTGATGACCAACTGCTCCAA } \\
\text { R: AGTCTGCGGGAACCTTTCTT } \\
\text { SYBRGreen }^{\circledR}\end{array}$ & Hs01935337_s1 \\
\hline IL-6 & & Hs00174131_m1 \\
\hline IL-8 & & Hs00174103_m1 \\
\hline $18 \mathrm{~S}$ & & Hs03003631_g1 \\
\hline TBP & & Hs00427620_m1 \\
\hline
\end{tabular}

TNF- $\alpha(0.1,1,10$, or 100$)$. All concentrations were shown to be non-toxic in advance using the MTT assay (data not shown).

After stimulation, cells were trypsinized, mRNA was isolated and reverse transcribed as described above. Realtime RT-PCR measurement was performed using TaqMan ${ }^{\circledR}$ Gene Expression assays for detection of toll-like receptors 2, 4 and 6 (chosen based on above mentioned experiments) as well as of TATA-box binding protein TBP (internal control). Gene expression was first normalized to the housekeeping gene before comparing expression of treated cells to untreated control ( $2^{-\Delta \Delta \mathrm{Ct}}$ method) [31]. Based on the results, TLR2 was further investigated.
Detection of changes in TLR protein expression upon stimulation with TNF- $\alpha$ or IL-1 $\beta$

For protein expression analysis, disc cells from three donors (degeneration grade 3-4) were treated with either $10 \mathrm{ng} / \mathrm{ml}$ IL- $1 \beta$ or $100 \mathrm{ng} / \mathrm{ml}$ TNF- $\alpha$ for $24 \mathrm{~h}$ as described above (concentration with strongest effect on gene expression). After stimulation, protein extracts were prepared from PBS-washed cells by scraping off cells with $150 \mu \mathrm{l}$ of SDS lysis buffer (120 mM Tris, $20 \%$ glycerol, $4 \%$ SDS), followed by sheering using a $27 \mathrm{G}$ needle. In addition, protein extracts of THP1 cells (monocytic leukemia cell line) were prepared as a 
positive control. Protein extracts were separated on a SDS-polyacrylamide gel and transferred to a PVDF membrane (Amersham, Switzerland) as previously described [32]. The membrane was incubated with a TLR2 antibody (AF2616, R\&D Systems, United Kingdom) followed by incubation with an appropriate HRP secondary antibody before analyzing chemiluminescence. Tubulin was used as a loading control.

Detection of changes in mRNA expression of proinflammatory genes upon stimulation with TNF$\alpha$, IL- $1 \beta$ or Pam3CSK4

Changes in the expression of TLR2 target genes IL-6 and IL-8 were measured in cells from five to seven patients (grade 3-4) which were first rendered serum free for $2 \mathrm{~h}$ before stimulating them for $18 \mathrm{~h}$ with recombinant IL-1 $\beta(5 \mathrm{ng} / \mathrm{ml})$, TNF- $\alpha(10 \mathrm{ng} / \mathrm{ml})$ or the known TLR2 ligand Pam3CSK4 (100 ng/ml; InvivoGen/Lab Force, Switzerland) in serum-free medium with streptomycin $(50 \mu \mathrm{g} / \mathrm{mL})$, ampicillin $(125 \mathrm{ng} / \mathrm{mL})$ and polymyxin B (which binds any possible LPS contamination; $10 \mu \mathrm{g} / \mathrm{ml}$, Sigma-Aldrich, Switzerland). The concentration for Pam3CSK4 was chosen based on preliminary studies which investigated cytotoxicity and inflammatory potential (see Supplementary Figure S1a/b/c). Changes in gene expression of IL- 6 and IL- 8 after $18 \mathrm{~h}$ of treatment were analyzed as described above (for primer details see Table 1).

Analysis of TLR activation upon stimulation with TNF$\alpha, \mathrm{IL}-1 \beta$ or Pam3CSK 4

To detect whether IL-1 $\beta$ and TNF- $\alpha$ stimulation leads to activation of TLR2 (the most appropriate TLR based on the above mentioned results), a specific TLR2 neutralizing antibody (pab-hstlr2; InvivoGen/Lab Force, Switzerland) at a concentration of $5 \mu \mathrm{g} / \mathrm{ml}$ was used to inhibit TLR2 binding capacity. Cell cultures of four patients (grade 3-4) were rendered serum free for $2 \mathrm{~h}$ and then preincubated with TLR2 neutralizing antibody for $1 \mathrm{~h}$, followed by adding IL- $1 \beta(5 \mathrm{ng} / \mathrm{ml})$, TNF- $\alpha$ $(10 \mathrm{ng} / \mathrm{ml})$ or Pam3CSK4 (100 ng/ml); the respective IgG control (rat IgG2b, Biolegend/LucernaChem, Switzerland) was included and data were calculated relative to this control. The concentration of TLR2 neutralizing antibody was chosen based on preliminary data, obtained by the measurement of changes in mRNA levels of IL-6 and IL-8 after dose-dependency experiment with pabhstlr2/Pam3CSK4 (data not shown). Changes in gene expression of IL- 6 and IL-8 after $18 \mathrm{~h}$ of treatment were analyzed as described before.
Analysis of down-stream activation of NF- $\kappa \mathrm{B}$ upon stimulation with TNF- $\alpha$, IL- $1 \beta$ or Pam3CSK4

As TLR activation can be linked to NF- $\kappa \mathrm{B}$ activation, two methods (immunocytochemistry, transcription factor assay) were used to determine NF- $\kappa \mathrm{B}$ activation upon stimulation with IL-1 $\beta$, TNF- $\alpha$ and Pam3CSK4.

Immunocytochemistry was used to detect nuclear translocation of p65 after stimulating cells seeded in 24-well plates with IL-1 $\beta(5 \mathrm{ng} / \mathrm{ml})$, TNF- $\alpha(10 \mathrm{ng} / \mathrm{ml})$ or Pam3CSK4 $(100 \mathrm{ng} / \mathrm{ml})$ (all $1 \mathrm{~h})$, with or without pretreatment with TLR2 neutralizing antibody $(1 \mathrm{~h})$ as described above. An untreated control, a negative control (no primary antibody) as well as an $\operatorname{IgG}$ control were included and a previously described method for staining was used [32]. Briefly, cells (grade 3-4) were fixed in icecold methanol, washed, blocked (1\% BSA, $0.1 \%$ Triton$\mathrm{X}$ in PBS) and incubated with p65 antibody (sc-372, Santa Cruz) for $60 \mathrm{~min}$ before fluorescence labeling with a specific secondary antibody. Nuclear counterstaining with DAPI was also performed.

Immunocytochemistry results were confirmed by a commercial NF- $\kappa B$ (p65) transcription factor assay (Cayman), which allows measuring NF- $\mathrm{BB}$ (p65) binding activity in nuclear extracts isolated from IVD cells that underwent the same treatment as described above. All absorbance measurements were carried out at $655 \mathrm{~nm}$.

Analysis of the role of HSP60, HSP70 and HMGB1 in TLR signaling during IVD inflammation

To identify whether the stress-related proteins (HSP60, HSP70, HMGB1) play a role in TLR signaling during inflammatory disc disease, changes in the mRNA expression of HSP60, HSP70 and HMGB1 upon stimulation with IL- $1 \beta$ and TNF- $\alpha$ were analyzed in human disc cells (grade 3-4) by real-time RT-PCR. Furthermore, IVD cells were rendered serum free for $2 \mathrm{~h}$ and then incubated with recombinant human HSP60 (Enzo Life Sciences: 0.1, 1.0 or $10 \mu \mathrm{g} / \mathrm{ml}$ ), HSP70 (Enzo Life Sciences: 0.1, 1.0 or $10 \mu \mathrm{g} / \mathrm{ml}$ ) or HMGB1 (Abnova: $0.05,0.1$ or $0.5 \mu \mathrm{g} / \mathrm{ml}$ ) (all in DMEM/F12 with penicillin, streptomycin, ampicillin and polymyxin as described above) before measuring changes in the expression of IL- 6 and IL- 8 by real-time RT-PCR (after $18 \mathrm{~h}$ ).

Statistical analysis

Quantified results were statistically analyzed by MannWhitney $U$ test for comparison between treatment groups and control group as well as by ANOVA and TukeyKramer HSD test for comparison between different groups, 
using the SPSS Statistics Program (SPPS 20.0.0). For all tests, the significance level was set to $p<0.05$.

\section{Results}

\section{Basal TLR gene expression}

Basal expression of TLRs was investigated in cultured, but untreated IVD cells of 6 different donors. As data are presented as $\Delta \mathrm{Ct}$ values, low values represent high expression and vice versa. We found TLR1, 6 and 10 to be highly expressed $(\Delta \mathrm{Ct}$ values $<10)$, while mRNA expression of TLR2, 3, 4, 5 and 9 was lower $(\Delta \mathrm{Ct}$ values $>10$ ) (Fig. 1a). TLR7 and TLR8 could not be detected in human IVD cells. As TLR2, 3 and 4 have been demonstrated to play a major role in osteoarthritis and rheumatoid arthritis [8, 29, 33], these TLRs-together with the highly expressed TLRs (TLR1/6/10) -were further investigated.
Changes in TLR mRNA expression with the degree of IVD degeneration

Tissue samples with different degrees of degeneration (4 grades, $n=5-10$ in each grade) were analyzed for TLR1, 2, 3, 4, 6 and 10 mRNA expression. While TLR3 and TLR10 expression did not depend on the degree of degeneration (see Supplementary Figure S2a/b), mRNA expression of TLR1 (Fig. 1b) TLR2 (Fig. 1c), TLR4 (Fig. 1d) and TLR6 (Fig. 1e) showed a statistically significant alteration during degeneration, with an increase in expression in the moderate and severe group. TLR1, TLR2, TLR4 and TLR6 were thus chosen for further investigations.

Changes in TLR gene expression after stimulation with TNF- $\alpha$ and IL-1 $\beta$

In the next step, we analyzed whether the expression of TLR1, TLR2, TLR4 and TLR6 is induced by TNF- $\alpha$ or a

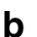

b

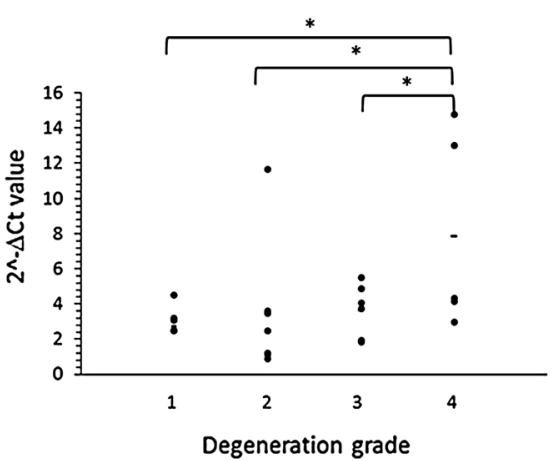

d

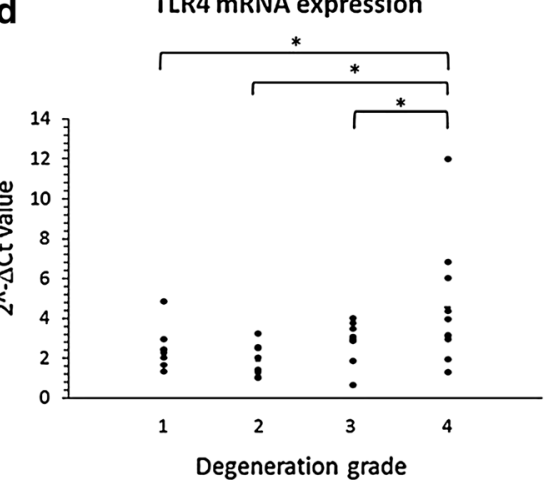

TLR2 mRNA expression
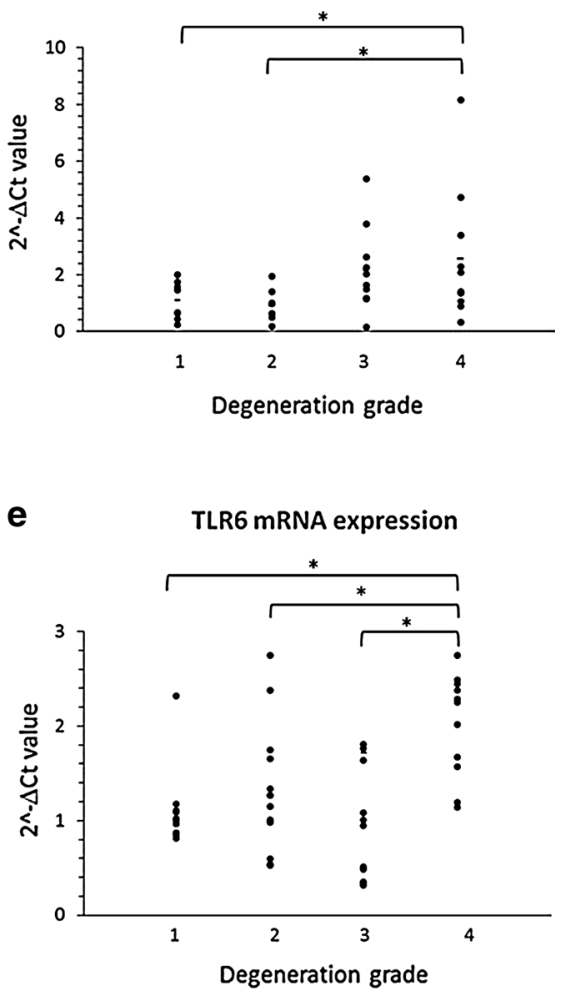

Fig. 1 Basal TLR mRNA expression and changes in TLR mRNA expression with the degree of IVD degeneration. Basal gene expression levels of TLR1, TLR2, TLR3, TLR4, TLR5, TLR6, TLR9 and TLR10 in expanded but untreated human disc cells (a), measured by real-time RT-PCR and calculated by the $\Delta \mathrm{Ct}$ method. Low values are thus representative of high expression and vice versa. Individual data points of six independent donors. TLR7/8 was not detectable. Gene expression of TLR1 (b), TLR2 (c), TLR4 (d) and
TLR6 (e) in IVD biopsies with different degrees of degeneration $(1=$ healthy; $2=$ mild degeneration; 3 = moderate degeneration; $4=$ severe degeneration), measured by real-time RT-PCR and calculated by the $2^{-\Delta \mathrm{Ct}}$ method. Individual data points of $5-10$ independent donors in each group. Asterisks indicate statistical significance between indicated groups (i.e. grades of degeneration) with $p<0.05$. (For TLR3 and TLR10 see Supplementary Figure S2a/ b) 
IL-1 $\beta$. When treating cells with $10 \mathrm{ng} / \mathrm{ml}$ TNF- $\alpha$ or $5 \mathrm{ng} /$ $\mathrm{ml}$ IL-1 $\beta$ or for 2,6 or $18 \mathrm{~h}$, we could observe an increase in TLR1 expression with TNF- $\alpha$ treatment (3.2 fold after $6 \mathrm{~h} ; 4.9$ fold after $18 \mathrm{~h}$ ) (Fig. 2a), but not with IL-1 $\beta$ treatment (Fig. 2b). TLR2 expression increased with both, TNF- $\alpha$ (Fig. 2 c) and IL-1 $\beta$ (Fig. 2d), with the highest effects after $18 \mathrm{~h}$. The increase in TLR2
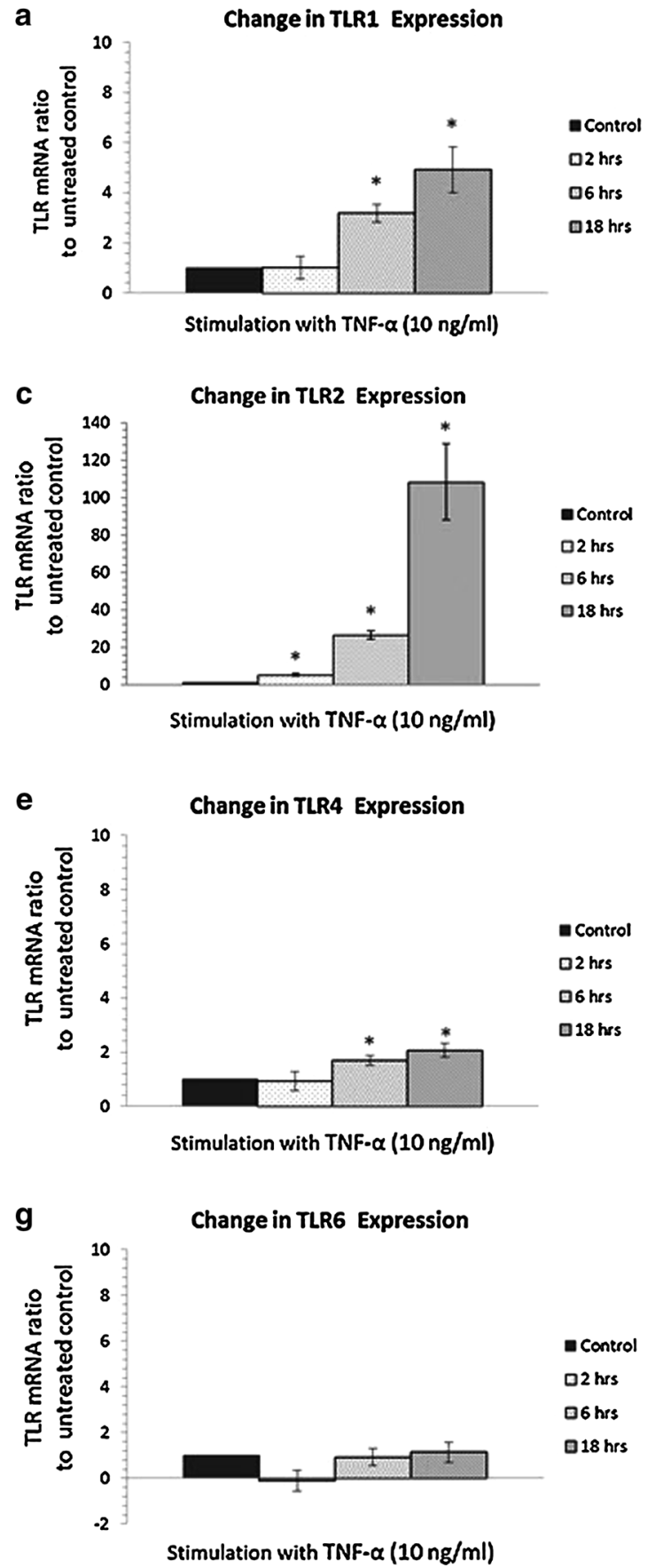

Fig. 2 Changes in TLR mRNA expression upon stimulation with TNF- $\alpha$ or IL-1 $\beta$ (time course). Fold changes in gene expression of TLR1 (a, b), TLR2 (c, d), TLR4 (e, f) and TLR6 (g, h) after stimulation with $10 \mathrm{ng} / \mathrm{ml} \mathrm{TNF}-\alpha(\mathbf{a}, \mathbf{c}, \mathbf{e}, \mathbf{g})$ or $5 \mathrm{ng} / \mathrm{ml} \mathrm{IL}-1 \beta(\mathbf{b}, \mathbf{d}, \mathbf{f}$, expression after TNF- $\alpha$ treatment (108.2 fold, $18 \mathrm{~h}$ ) was higher than after IL-1 $\beta$ treatment (7.5 fold, $18 \mathrm{~h})$. TNF- $\alpha$ treatment also slightly induced TLR4 expression (2.1 fold, $18 \mathrm{~h}$ ) (Fig. 2e), while stimulation with L-1 $\beta$ had no effect on TLR4 mRNA levels (Fig. 2f). No changes were observed for TLR6 expression after any treatment and at any time point (Fig. 2g, h).
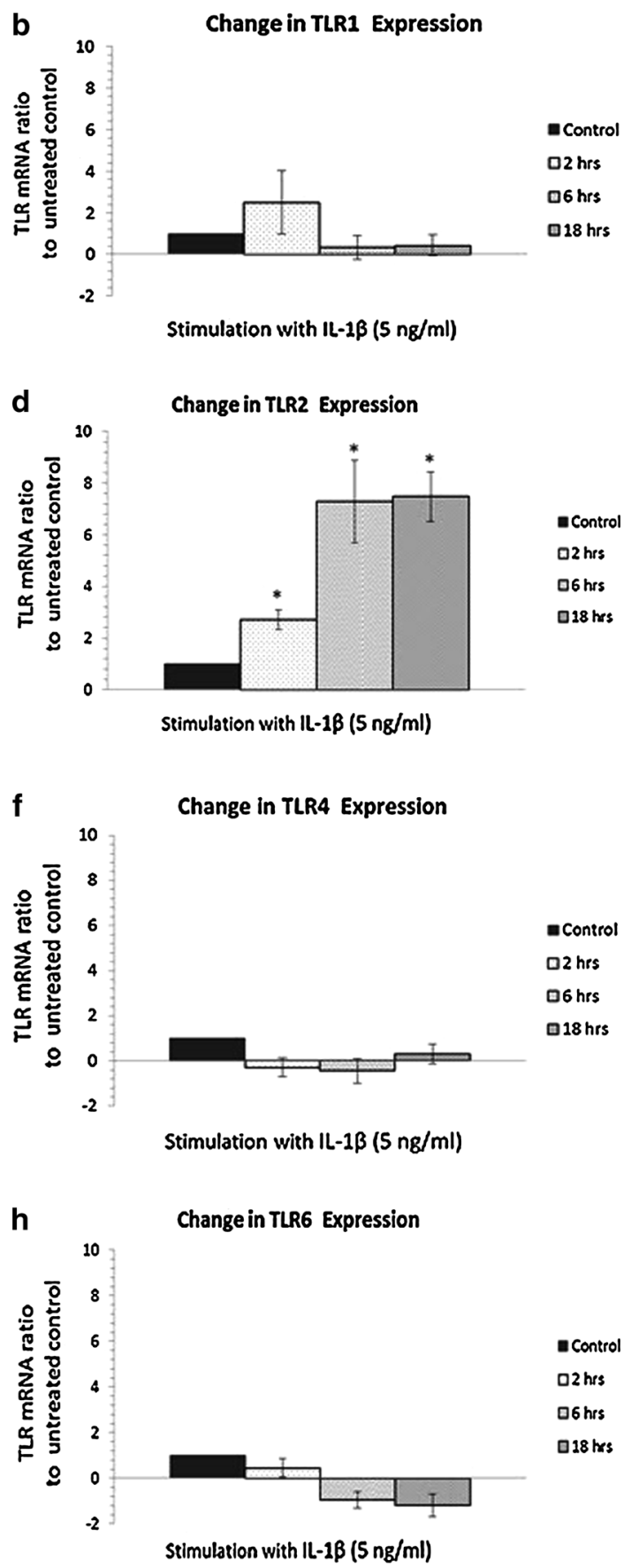

h) for 2,6 or $18 \mathrm{~h}$, measured by real-time RT-PCR and calculated by the $2^{-\Delta \Delta C t}$ method. Changes are calculated relative to untreated control cells. Mean \pm SEM of five independent donors. Asterisks indicate statistical significance relative to untreated control with $p<0.05$ 

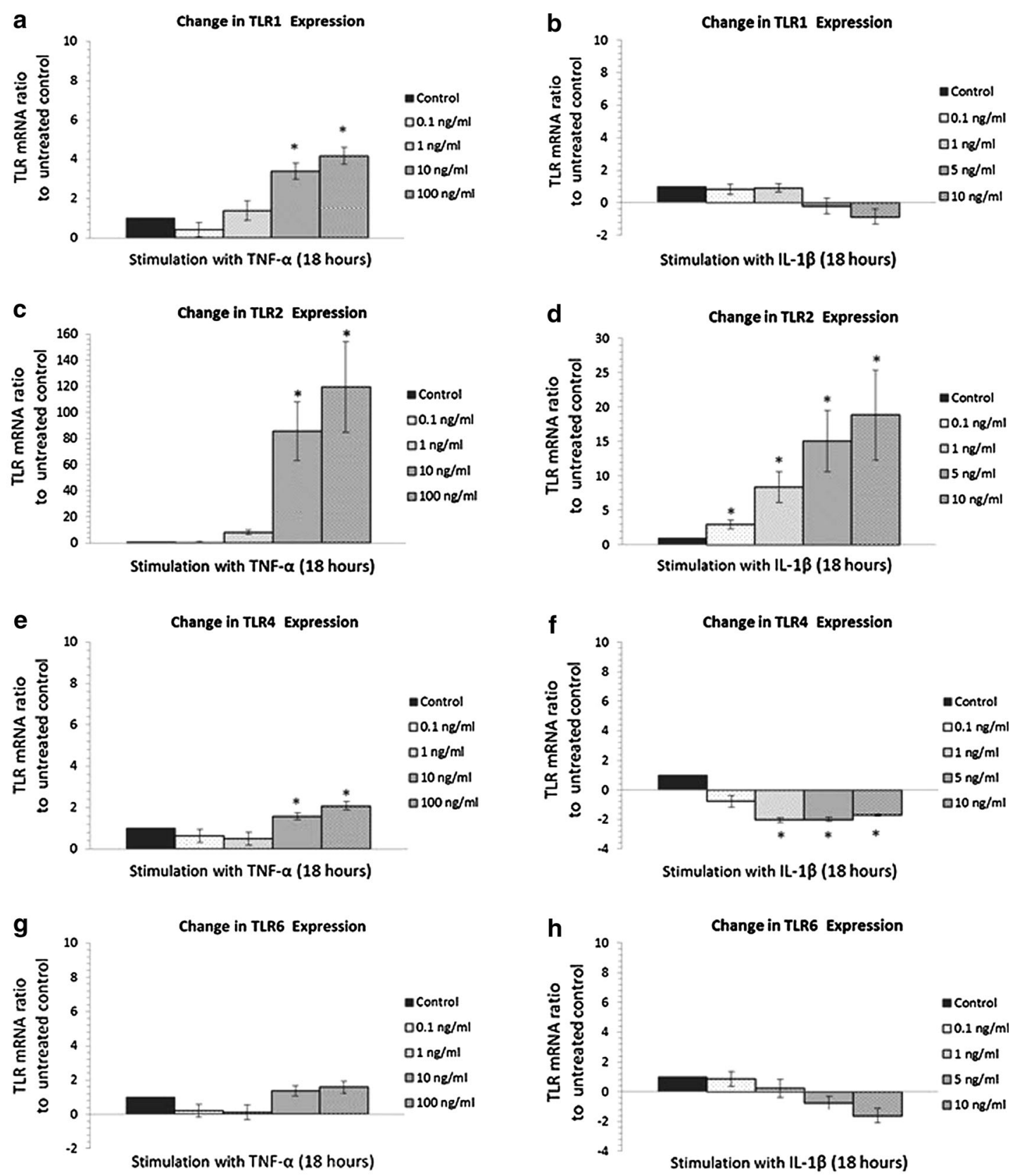

Stimulation of disc cells with different concentrations of TNF- $\alpha$ or IL- $1 \beta$ for $18 \mathrm{~h}$ resulted in changes in TLR gene expression similar to the time course experiments. TNF- $\alpha$ caused a dose-dependent increase in TLR1 expression (three to fourfold) (Fig. 3a), whereas IL-1 $\beta$ had no effect at any concentration (Fig. 3b). TNF- $\alpha$ and IL-1 $\beta$ both 
4Fig. 3 Changes in TLR mRNA expression (concentration dependency) and in TLR2 protein expression upon stimulation with TNF- $\alpha$ or IL-1 $\beta$. Fold changes in gene expression of TLR1 $(\mathbf{a}, \mathbf{b})$, TLR2 (c, d), TLR4 (e, f) and TLR6 (g, h) after stimulation with different concentrations of TNF- $\alpha(\mathbf{a}, \mathbf{c}, \mathbf{e}, \mathbf{g})$ or IL-1 $\beta(\mathbf{b}, \mathbf{d}, \mathbf{f}, \mathbf{h})$ for $18 \mathrm{~h}$, measured by real-time RT-PCR and calculated by the $2^{-\Delta \Delta \mathrm{Ct}}$ method. Changes are calculated relative to untreated control cells. Mean \pm SEM of five independent donors. Asterisks indicate statistical significance relative to untreated control with $p<0.05$. As TLR2 was regulated most on the gene expression level, TLR2 was chosen for protein expression analysis after stimulation with TNF- $\alpha$ (100 ng/ $\mathrm{ml})$ or IL-1 $\beta(10 \mathrm{ng} / \mathrm{ml})$ for $24 \mathrm{~h}(\mathbf{i})$. Stimulated samples are shown relative to untreated control cells, detected by immunoblotting (three independent donors, one representative picture). Extracts from THP1 cells are used as positive controls. The image has been cropped to improve clarity. Used TLR2 antibody: AF2616, R\&D Systems, $0.2 \mu \mathrm{g} / \mathrm{ml}$

induced TLR2 expression in a direct, concentrationdependent manner. Upon TNF- $\alpha$ treatment, TLR2 expression was induced 119.4 fold (Fig. 3c; $100 \mathrm{ng} / \mathrm{ml}$ ), while IL-1 $\beta$ treatment only caused an 18.9 fold induction (Fig. 3d, $10 \mathrm{ng} / \mathrm{ml}$ ). TLR4 expression was increased 2.1 fold by TNF- $\alpha$ treatment (Fig. $3 \mathrm{e}, 100 \mathrm{ng} / \mathrm{ml}$ ), whereas IL-

\section{a}

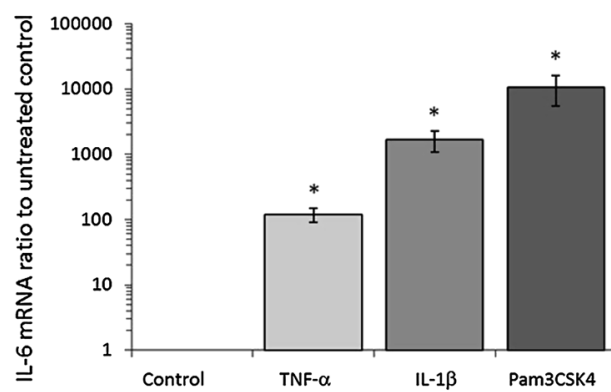

C

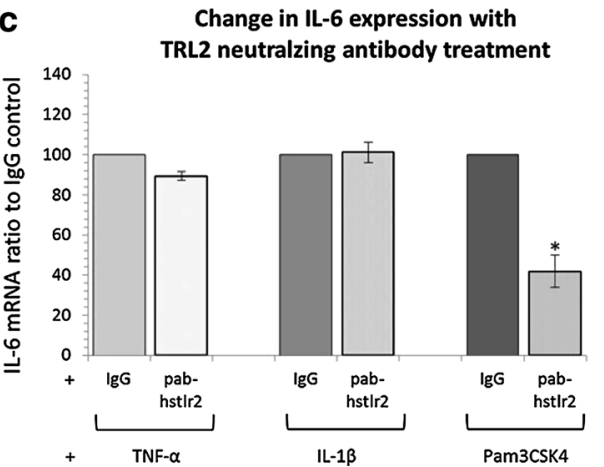

Fig. 4 Changes in mRNA expression of IL-6 and IL-8 upon stimulation with TNF- $\alpha$, IL-1 $\beta$ or Pam3CSK4 with or without TLR2 neutralizing antibody. Fold change in gene expression of the TLR2 target genes IL-6 (a) and IL-8 (b) after stimulation with $10 \mathrm{ng} /$ $\mathrm{ml} \mathrm{TNF-} \alpha, 5 \mathrm{ng} / \mathrm{ml} \mathrm{IL-1 \beta}$ or $100 \mathrm{ng} / \mathrm{ml}$ Pam3CSK 4 for $18 \mathrm{~h}$ (without TLR2 neutralizing antibody), relative to untreated control. Data obtained by real-time RT-PCR and calculated by the $2^{-\Delta \Delta \mathrm{Ct}}$ method. Mean \pm SEM of five to seven independent donors. Asterisks indicate statistical significance relative to untreated control with $p<0.05$.
$1 \beta$ treatment resulted in a slight reduction in mRNA expression at all concentrations (Fig. 3f). TLR6 expression was neither regulated by TNF- $\alpha$ nor by IL-1 $\beta$ (Fig. $3 g, h$ ).

While TLR1 and TLR4 were slightly induced upon TNF- $\alpha$ treatment, TLR 2 was strongly induced with both, IL-1 $\beta$ and TNF- $\alpha$ and was thus chosen for all further investigations.

Supplementary material As TLR3 has been described to be of importance in cartilage disease, changes in TLR3 expression upon stimulation with TNF- $\alpha$ and IL-1 $\beta$ were also measured. As shown in Supplementary Figure S3a/b, TNF- $\alpha$ treatment induced TLR3 expression at later time points and higher concentrations (up to tenfold), while IL-1 $\beta$ treatment had minor effects (see Supplementary Figure 3a-d).

Changes in TLR2 protein expression after stimulation with TNF- $\alpha$ and IL-1 $\beta$

On the protein level, stimulation with IL-1 $\beta$ and TNF- $\alpha$ also resulted in increased levels of TLR2 expression

b

Change in IL-8 expression
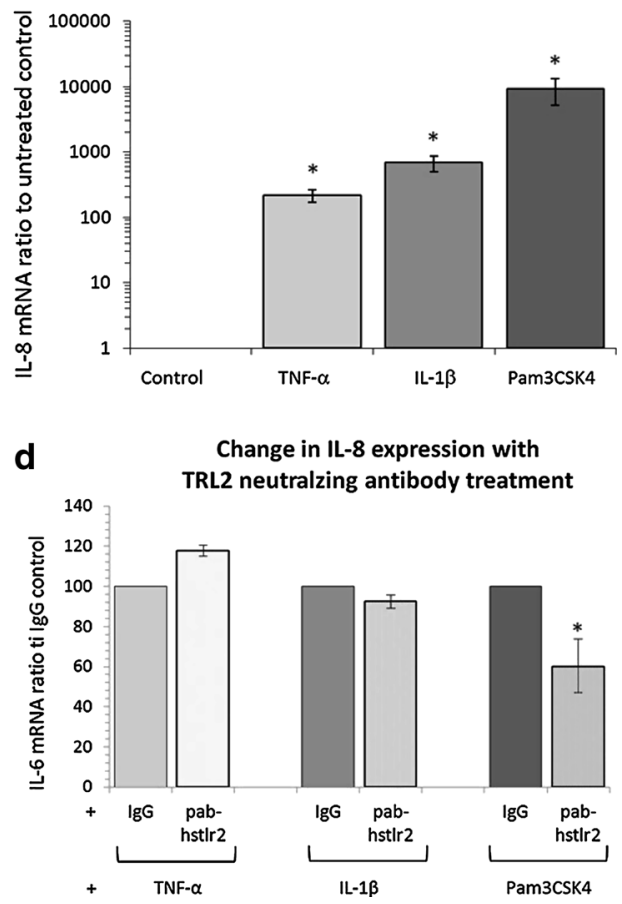

Prestimulation with $5 \mu \mathrm{g} / \mathrm{ml}$ neutralizing antibody (pabhstlr2, Invivogen) for $1 \mathrm{~h}$ before treatment with either $10 \mathrm{ng} / \mathrm{ml} \mathrm{TNF}-\alpha, 5 \mathrm{ng} / \mathrm{ml}$ IL- $1 \beta$ or $100 \mathrm{ng} / \mathrm{ml} \mathrm{Pam3CSK} 4$ for $18 \mathrm{~h}$. Fold change in gene expression of the TLR2 target genes IL-6 (c) and IL-8 (d) after $18 \mathrm{~h}$, relative to the respective $\mathrm{IgG}$ control (expression with $\mathrm{IgG}$ control is set to $100 \%$ ). Data obtained by real-time RT-PCR and calculated by the $2^{-\Delta \Delta \mathrm{Ct}}$ method. Mean \pm SEM of four independent donors. Asterisks indicate statistical significance relative to $\operatorname{IgG}$ control with $p<0.05$ 
(Fig. 3i; human THP1 cells as positive control). TLR2 was chosen for protein detection as it showed most prominent changes on the mRNA level (compared to TLR1 and TLR4, which were altered only slightly). Furthermore, commercial antibodies for the detection of TLR1 and TLR4 did not provide satisfactory results, either due to unspecificity or insensitivity [16] or because of too low expression levels in disc cells.

Changes in mRNA expression of proinflammatory genes after stimulation with TNF- $\alpha$, IL-1 $\beta$

or Pam3CSK4

When stimulating cells with $10 \mathrm{ng} / \mathrm{ml} \mathrm{TNF}-\alpha, 5 \mathrm{ng} / \mathrm{ml} \mathrm{IL}-$ $1 \beta$ or $100 \mathrm{ng} / \mathrm{ml}$ Pam3CSK4, an increase of IL-6 and IL-8 was observed: IL-6 mRNA expression was increased 120.1 fold by TNF- $\alpha, 1689.1$ fold by IL-1 $\beta$ and 10707.7 fold by Pam3CSK4 (see Fig. 4a); IL-8 mRNA expression was increased 218.5 fold by TNF- $\alpha, 682.3$ fold by IL- $1 \beta$ and 9202.2 fold by am3CSK4 (see Fig. 4b).

TLR2 activation upon stimulation with TNF- $\alpha$, IL-1 $\beta$ or Pam3CSK4

When prestimulating cells for $1 \mathrm{~h}$ with $5 \mu \mathrm{g} / \mathrm{ml}$ pabhstlr2 (a specific TLR2 neutralizing antibody) before adding TNF- $\alpha$, IL-1 $\beta$ or Pam3CSK4, levels of IL-6 were decreased in case the of Pam3CSK4 treatment $(-2.4$ fold: $100 \rightarrow 41.9 \%)$, but not in the case of TNF- $\alpha$ or IL-1 $\beta$ treatment (Fig. 4c). Similarly, the TLR2 neutralizing antibody reduced levels of IL-8 upon stimulation with Pam3CSK4 (1.7 fold: $100 \rightarrow 60.2 \%$ ), but not upon stimulation with TNF- $\alpha$ or IL-1 $\beta$ (Fig. $4 d$ ). Note that cells under inflammatory conditions, i.e. cells stimulated with Pam3CSK4, TNF- $\alpha$ or IL-1 $\beta$ plus the appropriate $\mathrm{IgG}$ control were used as a reference and set to $100 \%$.

NF- $\kappa \mathrm{B}$ activation upon stimulation with TNF- $\alpha$, IL-1 $\beta$ or Pam3CSK4

TNF- $\alpha$ and IL-1 $\beta$ caused nuclear translocation of p65 after $60 \mathrm{~min}$ of stimulation, which was not prevented by pretreatment with the TLR2 neutralizing antibody as shown by immunocytochemistry (Fig. 5a) and measurement of DNA binding activity (Fig. 5b). While immunocytochemistry did not reveal distinct effects for Pam3CSK4, the transcription factor assay clearly indicated the absence of increased DNA binding activity upon stimulation with Pam3CSK4 (Fig. 5a, b). This provides evidence that Pam3CSK4, despite activating TLR2, does not cause down-stream activation of $\mathrm{NF}-\kappa \mathrm{B}$.
Role of HSP60, HSP70 and HMGB1 in TLR signaling during IVD inflammation

We have previously demonstrated the expression of HSP60, HSP70 and HMGB1 in human IVD biopsies, although no clear correlation between expression levels and the degree of degeneration could be found (unpublished data). In this study, we found that stimulation of human IVD cells with IL-1 $\beta(5 \mathrm{ng} / \mathrm{ml})$ and TNF- $\alpha(10 \mathrm{ng} / \mathrm{ml})$ did not alter the expression of HSP60 and only very slightly induced expression of HSP70 (1.5 fold increase with IL-1 $\beta$ ) and HMGB1 (1.3 fold with TNF- $\alpha$ ) (Supplementary Figure 4ac). HSPs and HMGB1 had minor inflammatory properties in human IVD cells. Stimulation with recombinant HSP60 did not have any effect and HSP70 only slightly induced IL-6 (3.6 fold) increase and IL-8 (2.7 fold increase), but only at the highest concentration of $10 \mu \mathrm{g} / \mathrm{ml}$. In contrast, HMGB1 caused a minor inhibition of IL-6 expression (2.2 fold decrease) and had no effect on IL-8 mRNA levels (see Supplementary Figure 5a-f).

\section{Discussion}

In the present study, we found that TLR1, 2, 3, 4, 5, 6, 9 and 10 were expressed in human IVD cells, while only TLR1, TLR2, TLR4, and TLR6 were dependent on the degree of IVD degeneration. So far, only TLR2 and TLR4 have been described by us [34, 35] and others [36-38] to be expressed in human [34, 35, 37, 38] or in bovine IVD cells [36-38]. TNF- $\alpha$, a physiological inflammatory signal, slightly induced TLR1 and TLR4 gene expression, whereas it strongly increased TLR2 gene and protein expression; expression of TLR3 (although not correlating to the degree of degeneration) was also induced by TNF- $\alpha$. IL-1 $\beta$ also induced TLR2 gene and protein expression, but not TLR1 and TLR4 gene expression. Although IL-1 $\beta$ and TNF- $\alpha$ caused an increase in TLR2, these mediators did not activate TLR2 expression, i.e. they do not act as TLR2 ligands in human IVD cells, whereas Pam3CSK4 does.

This is, to our knowledge, the first study that investigates the expression and regulation of TLRs in human IVD cells in a comprehensive manner. Our results clearly indicate that IL-1 $\beta$ and $\mathrm{TNF}-\alpha$, two of the major proinflammatory cytokines that are present during degenerative IVD disease [4, 39], induce TLR2 gene and protein expression. On the other hand, only a slight induction of TLR4 gene expression upon TNF- $\alpha$ stimulation was observed. Similarly, a prominent up-regulation of TLR2 but no regulation of TLR4 has been described upon stimulation with IL-1 $\beta$ and especially TNF- $\alpha$ in tenocytes [40]. Kim et al. [41] described a slight but significant induction of TLR2 mRNA expression (twofold increase) with IL-1 $\beta$ 
Fig. 5 Activation of NF- $\kappa B$ upon stimulation with TNF- $\alpha$, IL-1 $\beta$ or Pam3CSK4.

Prestimulation with $5 \mu \mathrm{g} / \mathrm{ml}$ neutralizing antibody (pabhstlr2) for $1 \mathrm{~h}$ before treatment with either $10 \mathrm{ng} / \mathrm{ml}$ $\mathrm{TNF}-\alpha, 5 \mathrm{ng} / \mathrm{ml}$ IL- $1 \beta$ or $100 \mathrm{ng} / \mathrm{ml}$ Pam3CSK4 for $1 \mathrm{~h}$. For detection of p65, a specific $\mathrm{NF}-\kappa \mathrm{B} / \mathrm{p} 65$ antibody was used for immunocytochemistry, with a representative picture of three independent donors being shown (a). P65/NF- $\kappa \mathrm{B}$ binding activity in nuclear extracts was determined by a commercial transcription factor assay.

Mean \pm SD of three

independent donors. Asterisks indicate statistical significance relative to untreated control with $p<0.05$ and hash keys indicate statistical significance to the respective neutralizing antibody group with $p<0.05$ (b) a
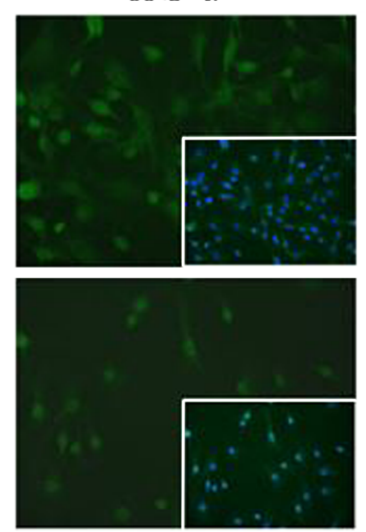

Untreated control
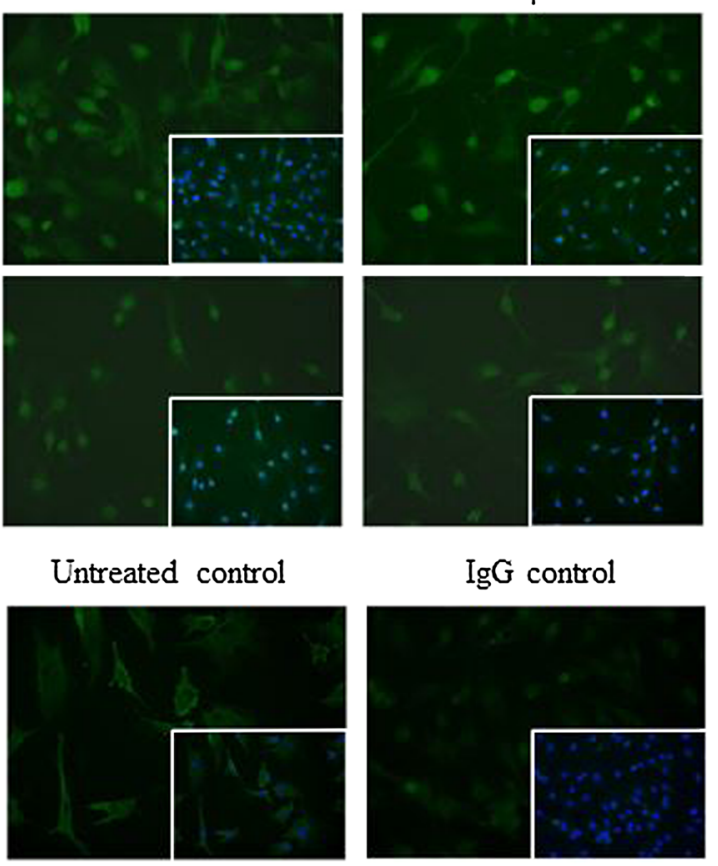

IgG control
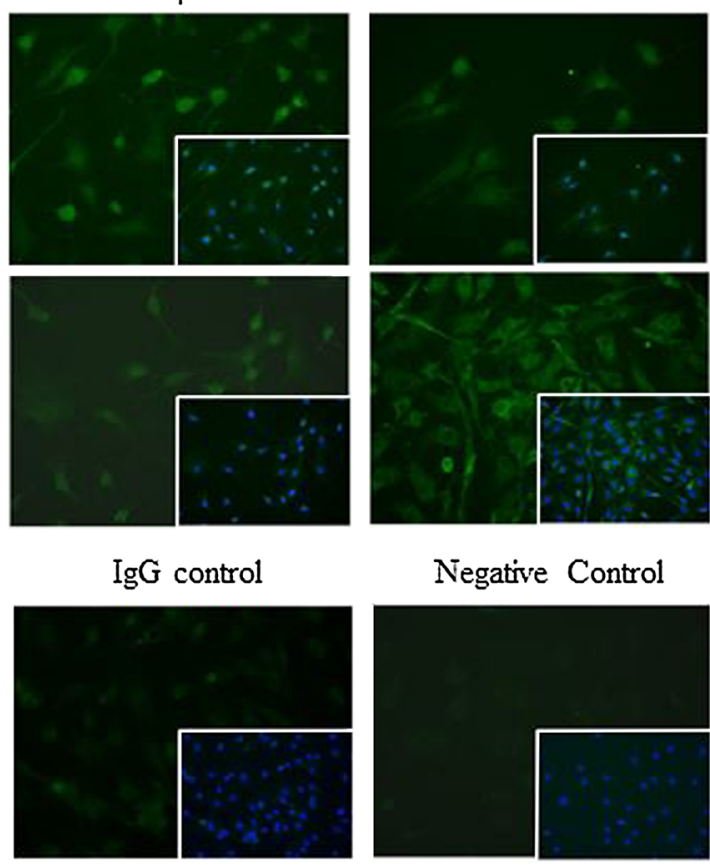

without

pabhstrl2

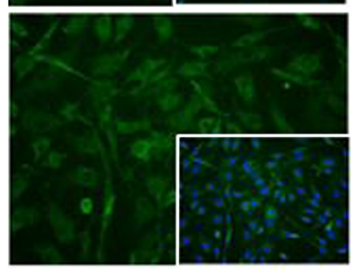

Negative Control

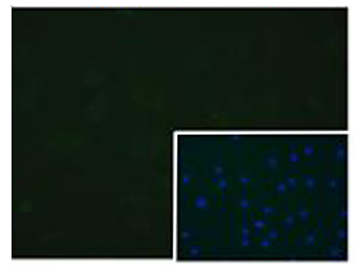

b

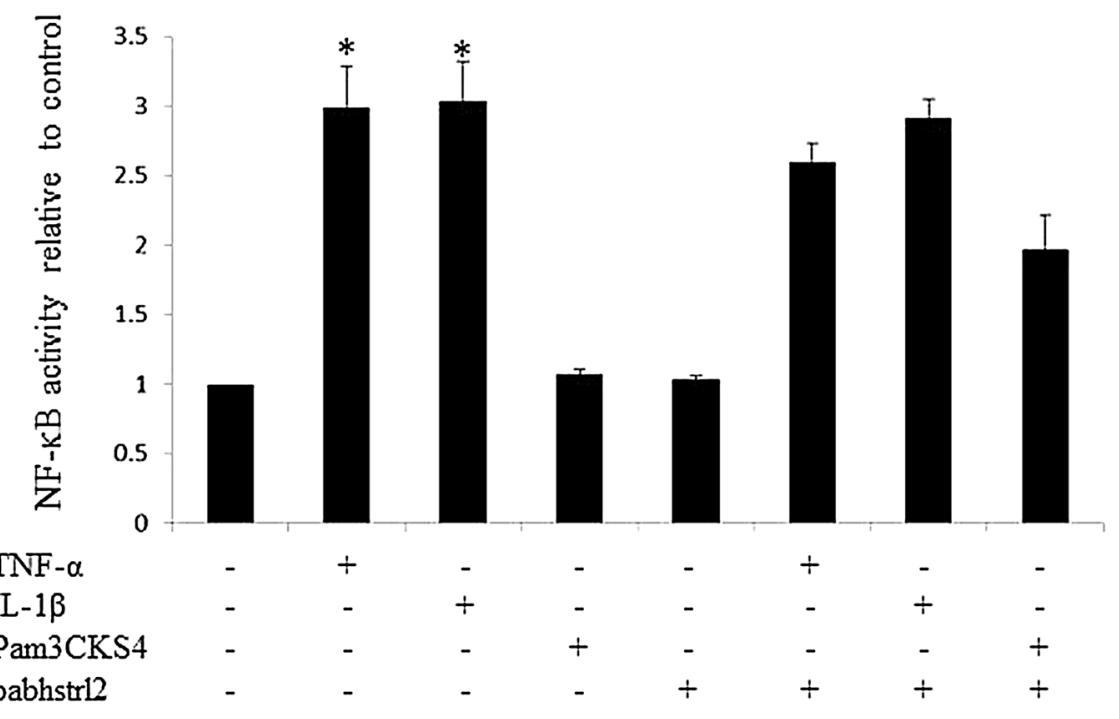

treatment and comparable results were published by Ellman et al. [37], using IVD cells. In human MSCs, inflammation (caused by a cocktail of IL- $1 \beta$, TNF- $\alpha$, INF$\alpha$, and INF- $\gamma$ ) increased TLR 2 and TLR4 expression, also with highest effects for TLR2 [42]. When comparing the responsiveness of TLR2 and TLR4 to IL- $1 \beta$ treatment in human epithelial cells and OA chondrocytes, it was found that-similar to our own data-only TLR2 expression was up-regulated [11, 43]. Despite similarities in the above described TLR data, variances amongst cell types seem to exist. Therefore, it is likely that the chondrocyte-like NP cells and the fibroblast-like AF cells show certain differences in both, the expression and regulation of TLRs, which we were not able to detect using human surgical disc material. While human biopsies cannot be accurately separated into NP and AF, experiments on e.g. bovine IVDs could elucidate zonal differences.

TLRs have long been described to detect pathogens and thus activate the innate immune system [13]. Due to its ability to build heterodimers with other TLRs and to use co-receptors for the recognition of certain molecules, TLR2 is proposed to have the largest number of ligands [44]. TLR2 ligands thus not only include bacterial components (e.g. peptidoglycan, lipoteichoic acid or lipoarabinomannan), but also endogenous components such as heat shock proteins, HMGB1 or matrix fragments 
(summarized in [45]), which are produced in case of stress, inflammation or disease [46-48]. As IL-1 $\beta$ and TNF- $\alpha$ induced TLR2 expression in IVD cells in our experiments as well as in other cell types as described in already published studies [11, 40-43], we were interested in understanding whether IL- $1 \beta$ or TNF- $\alpha$ directly activate TLR2 via ligand-receptor-binding-instead of solely leading to an inflammatory environment that favors the production of endogenous TLR ligands. However, our results using a chemical inhibitor of TLR2 (i.e. a specific TLR2 neutralizing antibody) clearly show that neither IL$1 \beta$ nor TNF- $\alpha$ activate TLR2 in human IVD cells. Furthermore, IL-1 $\beta$ and TNF- $\alpha$ activate the transcription factor $\mathrm{NF}-\kappa \mathrm{B}$ (i.e. cause nuclear translocation of $\mathrm{p} 65$ ), but this effect was not mediated via the TLR2 pathway, thus further confirming that IL-1 $\beta$ and TNF- $\alpha$ do not act as TLR ligands.

Although TLR2 is neither activated directly by IL-1 $\beta$ nor by TNF- $\alpha$, TLRs may still play a major role in inflammatory signaling during degenerative IVD disease. As described above, the inflammatory environment in the IVD in vivo may cause induction of endogenous TLR ligands, similar to cartilage (reviewed in [33]). From the large variety of possible endogenous ligands, we tested whether the stress-related proteins HSP60, HSP70 and HMGB1, which are expressed in human IVD tissue (unpublished data), play a role in TLR signaling during inflammatory IVD disease. However, IVD inflammation (i.e. IL-1 $\beta / \mathrm{TNF}-\alpha$ ) did not increase the expression of the analyzed candidates in human IVD cells. Furthermore, HSP60, HSP70 and HMGB1 showed no inflammatory capacity, indicating that they do not play a role in TLR/NF$\kappa \mathrm{B}$ signaling in the human IVD. However, IL- $1 \beta$ and TNF$\alpha$ may lead to formation of other potential endogenous ligands. In fact, IL-1 $\beta$ and TNF- $\alpha$ has been shown to stimulate expression of hyaluronidases and thus accumulation of hyaluronic acid fragments [49], whose inflammatory properties have been described e.g. in cartilage [48, 50]. Indeed, we were able to demonstrate most recently that small fragments of hyaluronic acid (6-12 disaccharides) act as TLR2 ligands and thus induce an inflammatory and catabolic cascade by downstream activation of the MAP Kinase pathway [16].

Importantly, TLR-ligand interaction can lead to activation of NF- $\kappa \mathrm{B}$ and MAPK, which has also been detected under specific conditions in IVD cells in vitro and in vivo (reviewed in [7, 33]). The potential role for TLRs in degenerative IVD disease is further underlined by the fact that TLRs control the expression of numerous proinflammatory cytokines (e.g. IL-1, IL-6, TNF- $\alpha$ ), chemokines (e.g. IL-8) and matrix metalloproteinases [8, 51, 52] that are all fundamental in the pathophysiological processes of the IVD [53]. As our study demonstrated that proinflammatory cytokines can induce TLR2 expression and as TLRs mediate inflammatory and catabolic responses upon ligand binding (e.g. via activation of MAPK as demonstrated for hyaluronic acid fragments [16]) a selfsustaining inflammatory loop may exist under certain conditions in vivo. Therefore, the in vivo formation of endogenous TLR ligands such as hyaluronic acid fragments [54] or other yet unknown endogenous proteins can lead to the activation of the TLR signaling pathway and thus downstream stimulation of catabolic and inflammatory mediators. Interfering with the TLR signaling pathway, e.g. via inhibition of TLR2, could provide a molecular approach to prevent further tissue damage and inflammation, thus possibly representing a novel therapeutic option to treat painful degenerative disc disease.

\section{Conclusion}

In this study, we provide evidence that several TLRs are expressed in human IVD cells, with TLR1, TLR2, TLR4 and TLR6 expression being dependent on the degree of IVD degeneration. TLR1 and TLR4 gene expression, and more strongly TLR2 gene and protein expression is increased by proinflammatory cytokines (IL-1 $\beta, \mathrm{TNF}-\alpha$ ), although these substances do not activate TLR2. However, we were able to demonstrate most recently that small hyaluronic acid fragments act as TLR2 ligands, thus inducing inflammatory and catabolic processes. Based on these results, therapeutic targeting of TLR2 could represent a successful strategy to treat patients with painful degenerative disc disease.

Acknowledgments This study was made possible by grants from AOSpine (SRN 02/103) as well as by the Mäxi Foundation (CAB$\mathrm{MM}$ ). Its contents are solely the responsibility of the authors and do not necessarily represent the official views of AOSpine or of the Mäxi Foundation. We thank Dr. Wojtal from the University Hospital Zurich for providing THP1 cells.

Conflict of interest None.

\section{References}

1. Urban JP, Roberts S (2003) Degeneration of the intervertebral disc. Arthritis Res Ther 5:120-130

2. Fraser RD, Osti OL, Vernon-Roberts B (1993) Intervertebral disc degeneration. Eur Spine J 1:205-213

3. Bachmeier BE, Nerlich AG, Weiler C, Paesold G, Jochum M, Boos N (2007) Analysis of tissue distribution of TNF-alpha, TNF-alpha-receptors, and the activating TNF-alpha-converting enzyme suggests activation of the TNF-alpha system in the aging intervertebral disc. Ann N Y Acad Sci 1096:44-54 
4. Le Maitre CL, Freemont AJ, Hoyland JA (2005) The role of interleukin-1 in the pathogenesis of human intervertebral disc degeneration. Arthritis Res Ther 7:R732-R745

5. Burke JG, Watson RW, McCormack D, Dowling FE, Walsh MG, Fitzpatrick JM (2002) Intervertebral discs which cause low back pain secrete high levels of proinflammatory mediators. J Bone Joint Surg Br 84:196-201

6. Le Maitre CL, Pockert A, Buttle DJ, Freemont AJ, Hoyland JA (2007) Matrix synthesis and degradation in human intervertebral disc degeneration. Biochem Soc Trans 35:652-655

7. Wuertz K, Vo N, Kletsas D, Boos N (2012) Inflammatory and catabolic signalling in intervertebral discs: the roles of NF-kappaB and MAP kinases. Eur Cells Mater 23:103-119 (discussion 119-120)

8. Seibl R, Birchler T, Loeliger S, Hossle JP, Gay RE, Saurenmann T, Michel BA, Seger RA, Gay S, Lauener RP (2003) Expression and regulation of toll-like receptor 2 in rheumatoid arthritis synovium. Am J Pathol 162:1221-1227

9. Kyburz D, Rethage J, Seibl R, Lauener R, Gay RE, Carson DA, Gay S (2003) Bacterial peptidoglycans but not CpG oligodeoxynucleotides activate synovial fibroblasts by toll-like receptor signaling. Arthritis Rheum 48:642-650

10. Liu-Bryan R, Pritzker K, Firestein GS, Terkeltaub R (2005) TLR2 signaling in chondrocytes drives calcium pyrophosphate dihydrate and monosodium urate crystal-induced nitric oxide generation. J Immunol 174:5016-5023

11. Su SL, Tsai CD, Lee CH, Salter DM, Lee HS (2005) Expression and regulation of toll-like receptor 2 by IL-1beta and fibronectin fragments in human articular chondrocytes. Osteoarthritis Cartilage 13:879-886

12. Seibl R, Kyburz D, Lauener RP, Gay S (2004) Pattern recognition receptors and their involvement in the pathogenesis of arthritis. Curr Opin Rheumatol 16:411-418

13. Takeda K, Kaisho T, Akira S (2003) Toll-like receptors. Ann Rev Immunol 21:335-376. doi:10.1146/annurev.immunol.21.120601. 141126

14. Werts C, Tapping RI, Mathison JC, Chuang TH, Kravchenko V, Saint Girons I, Haake DA, Godowski PJ, Hayashi F, Ozinsky A, Underhill DM, Kirschning CJ, Wagner H, Aderem A, Tobias PS, Ulevitch RJ (2001) Leptospiral lipopolysaccharide activates cells through a TLR2-dependent mechanism. Nat Immunol 2:346-352

15. Iwaki D, Mitsuzawa H, Murakami S, Sano H, Konishi M, Akino T, Kuroki Y (2002) The extracellular toll-like receptor 2 domain directly binds peptidoglycan derived from Staphylococcus aureus. J Biol Chem 277:24315-24320

16. Quero L, Klawitter M, Schmaus A, Rothley M, Sleeman J, Tiaden AN, Klasen J, Boos N, Hottiger MO, Wuertz K, Richards PJ (2013) Hyaluronic acid fragments enhance the inflammatory and catabolic response in human intervertebral disc cells through modulation of toll-like receptor 2 signalling pathways. Arthritis Res Ther 15:R94

17. Dybdahl B, Wahba A, Lien E, Flo TH, Waage A, Qureshi N, Sellevold OF, Espevik T, Sundan A (2002) Inflammatory response after open heart surgery: release of heat-shock protein 70 and signaling through toll-like receptor-4. Circulation 105:685-690

18. Hwang D (2001) Modulation of the expression of cyclooxygenase- 2 by fatty acids mediated through toll-like receptor 4-derived signaling pathways. FASEB J 15:2556-2564

19. Ohashi K, Burkart V, Flohe S, Kolb H (2000) Cutting edge: heat shock protein 60 is a putative endogenous ligand of the toll-like receptor-4 complex. J Immunol 164:558-561

20. Yu M, Wang H, Ding A, Golenbock DT, Latz E, Czura CJ, Fenton MJ, Tracey KJ, Yang H (2006) HMGB1 signals through toll-like receptor (TLR) 4 and TLR2. Shock 26:174-179

21. Kim SC, Stice JP, Chen L, Jung JS, Gupta S, Wang Y, Baumgarten G, Trial J, Knowlton AA (2009) Extracellular heat shock protein 60, cardiac myocytes, and apoptosis. Circ Res 105:1186-1195

22. Ozato K, Tsujimura H, Tamura T (2002) Toll-like receptor signaling and regulation of cytokine gene expression in the immune system. Biotechniques 33:S66-S68

23. Fieber C, Baumann P, Vallon R, Termeer C, Simon JC, Hofmann M, Angel P, Herrlich P, Sleeman JP (2004) Hyaluronan-oligosaccharide-induced transcription of metalloproteases. J Cell Sci 117:359-367

24. Vazquez de Lara LG, Umstead TM, Davis SE, Phelps DS (2003) Surfactant protein A increases matrix metalloproteinase-9 production by THP-1 cells. Am J Physiol Lung Cell Mol Physiol 285:L899-L906

25. Takeuchi O, Hoshino K, Akira S (2000) Cutting edge: TLR2deficient and MyD88-deficient mice are highly susceptible to Staphylococcus aureus infection. J Immunol 165:5392-5396

26. Chow JC, Young DW, Golenbock DT, Christ WJ, Gusovsky F (1999) Toll-like receptor-4 mediates lipopolysaccharide-induced signal transduction. J Biol Chem 274:10689-10692

27. Pfirrmann CW, Metzdorf A, Zanetti M, Hodler J, Boos N (2001) Magnetic resonance classification of lumbar intervertebral disc degeneration. Spine 26:1873-1878

28. Tiaden AN, Klawitter M, Lux V, Mirsaidi A, Bahrenberg G, Glanz S, Quero L, Liebscher T, Wuertz K, Ehrmann M, Richards PJ (2012) Detrimental role for human high temperature requirement serine protease A1 (HTRA1) in the pathogenesis of intervertebral disc (IVD) degeneration. J Biol Chem 287:21335-21345

29. Ospelt C, Brentano F, Rengel Y, Stanczyk J, Kolling C, Tak PP, Gay RE, Gay S, Kyburz D (2008) Overexpression of toll-like receptors 3 and 4 in synovial tissue from patients with early rheumatoid arthritis: toll-like receptor expression in early and longstanding arthritis. Arthritis Rheum 58:3684-3692

30. Wuertz K, Godburn K, MacLean JJ, Barbir A, Donnelly JS, Roughley PJ, Alini M, Iatridis JC (2009) In vivo remodeling of intervertebral discs in response to short- and long-term dynamic compression. J Orthop Res 27:1235-1242

31. Livak KJ, Schmittgen TD (2001) Analysis of relative gene expression data using real-time quantitative PCR and the 2(-delta delta $\mathrm{C}(\mathrm{T})$ ) method. Methods 25:402-408

32. Wuertz K, Quero L, Sekiguchi M, Klawitter M, Nerlich A, Konno S, Kikuchi S, Boos N (2011) The red wine polyphenol resveratrol shows promising potential for the treatment of nucleus pulposus-mediated pain in vitro and in vivo. Spine 36:E1373E1384

33. Huang QQ, Pope RM (2009) The role of toll-like receptors in rheumatoid arthritis. Curr Rheumatol Rep 11:357-364

34. Klawitter M, Quero L, Klasen J, Liebscher T, Nerlich A, Boos N, Wuertz K (2012) Triptolide exhibits anti-inflammatory, anticatabolic as well as anabolic effects and suppresses TLR expression and MAPK activity in IL-1beta treated human intervertebral disc cells. Eur Spine J 21(Suppl 6):S850-S859

35. Klawitter M, Quero L, Klasen J, Gloess A, Klopprogge B, Hausmann O, Boos N, Wuertz K (2012) Curcuma DMSO extracts and curcumin exhibit an anti-inflammatory and anti-catabolic effect on human intervertebral disc cells, possibly by influencing TLR2 expression and JNK activity. J Inflamm (Lond) 9:29

36. Rajan NE, Bloom O, Maidhof R, Stetson N, Sherry B, Levine M, Chahine NO (2013) Toll-like receptor 4 (TLR4) expression and stimulation in a model of intervertebral disc inflammation and degeneration. Spine 38:1343-1351

37. Ellman MB, Kim JS, An HS, Chen D, Kc R, An J, Dittakavi T, van Wijnen AJ, Cs-Szabo G, Li X, Xiao G, An S, Kim SG, Im HJ (2012) Toll-like receptor adaptor signaling molecule MyD88 on intervertebral disk homeostasis: in vitro, ex vivo studies. Gene 505:283-290 
38. Gawri R, Rosenzweig DH, Krock E, Ouellet JA, Stone LS, Quinn TM, Haglund L (2014) High mechanical strain of primary intervertebral disc cells promotes secretion of inflammatory factors associated with disc degeneration and pain. Arthritis Res Ther 16:R21

39. Nerlich AG, Bachmeier BE, Schleicher E, Rohrbach H, Paesold G, Boos N (2007) Immunomorphological analysis of RAGE receptor expression and NF-kappaB activation in tissue samples from normal and degenerated intervertebral discs of various ages. Ann N Y Acad Sci 1096:239-248

40. de Mos M, Joosten LA, Oppers-Walgreen B, van Schie JT, Jahr H, van Osch GJ, Verhaar JA (2009) Tendon degeneration is not mediated by regulation of Toll-like receptors 2 and 4 in human tenocytes. J Orthop Res 27:1043-1047

41. Kim HA, Cho ML, Choi HY, Yoon CS, Jhun JY, Oh HJ, Kim HY (2006) The catabolic pathway mediated by Toll-like receptors in human osteoarthritic chondrocytes. Arthritis Rheum 54:2152-2163

42. Raicevic G, Rouas R, Najar M, Stordeur P, Boufker HI, Bron D, Martiat P, Goldman M, Nevessignsky MT, Lagneaux L (2010) Inflammation modifies the pattern and the function of toll-like receptors expressed by human mesenchymal stromal cells. Hum Immunol 71:235-244

43. Sakai A, Han J, Cato AC, Akira S, Li JD (2004) Glucocorticoids synergize with IL-1beta to induce TLR2 expression via MAP Kinase Phosphatase-1-dependent dual Inhibition of MAPK JNK and p38 in epithelial cells. BMC Mol Biol 5:2

44. Janeway CA Jr, Medzhitov R (2002) Innate immune recognition. Ann Rev Immunol 20:197-216

45. Erridge C (2010) Endogenous ligands of TLR2 and TLR4: agonists or assistants? J Leukoc Biol 87:989-999

46. Van Eden W, Wick G, Albani S, Cohen I (2007) Stress, heat shock proteins, and autoimmunity: how immune responses to heat shock proteins are to be used for the control of chronic inflammatory diseases. Ann N Y Acad Sci 1113:217-237

47. Harris HE, Andersson U, Pisetsky DS (2012) HMGB1: a multifunctional alarmin driving autoimmune and inflammatory disease. Nat Rev Rheumatol 8:195-202

48. Sofat N (2009) Analysing the role of endogenous matrix molecules in the development of osteoarthritis. Int J Exp Pathol 90:463-479

49. Flannery CR, Little CB, Hughes CE, Caterson B (1998) Expression and activity of articular cartilage hyaluronidases. Biochem Biophys Res Commun 251:824-829

50. Campo GM, Avenoso A, D’Ascola A, Prestipino V, Scuruchi M, Nastasi G, Calatroni A, Campo S (2012) Hyaluronan differently modulates TLR-4 and the inflammatory response in mouse chondrocytes. BioFactors 38:69-76

51. Radstake TR, Roelofs MF, Jenniskens YM, Oppers-Walgreen B, van Riel PL, Barrera P, Joosten LA, van den Berg WB (2004) Expression of toll-like receptors 2 and 4 in rheumatoid synovial tissue and regulation by proinflammatory cytokines interleukin12 and interleukin-18 via interferon-gamma. Arthritis Rheum 50:3856-3865

52. Brentano F, Schorr O, Gay RE, Gay S, Kyburz D (2005) RNA released from necrotic synovial fluid cells activates rheumatoid arthritis synovial fibroblasts via toll-like receptor 3. Arthritis Rheum 52:2656-2665

53. Podichetty VK (2007) The aging spine: the role of inflammatory mediators in intervertebral disc degeneration. Cell Mol Biol (Noisy-le-grand) 53:4-18

54. Esser PR, Wolfle U, Durr C, von Loewenich FD, Schempp CM, Freudenberg MA, Jakob T, Martin SF (2012) Contact sensitizers induce skin inflammation via ROS production and hyaluronic acid degradation. PLoS ONE 7:e41340 